\title{
Detecting Brugia Malayi in Lymphatic Filariasis Mosquito Vector in North Hulu Sungai District, South Kalimantan, Indonesia
}

\author{
Nita Rahayu ${ }^{1, *}$, Yuniarti Suryatinah ${ }^{1}$, M. Rasyid Ridha ${ }^{1}$, Harninda Kusumaningtyas ${ }^{1}$, \\ Mara Ipa ${ }^{2}$, Pandji Wibawa Dhewantara ${ }^{2}$
}

${ }^{1}$ Tanah Bumbu Unit for Health Research and Development South Kalimantan, Indonesia

${ }^{2}$ Pangandaran Unit for Health Research and Development West Java, Indonesia

"Corresponding author. Email: nita.rahayu79@yahoo.co.id

\begin{abstract}
Mansonia is one of the genera of mosquitoes that play a role in the transmission of filariasis in North Hulu Sungai Utara undertook mass treatment of entire endemic communities from 2006 to 2015 to eliminate the transmission of the disease. However, post validation surveillance activities are required to ensure the gains achieved are sustained. Entomological survey was carried out to assess the mosquito vectors of the disease and determined the presence of infection in these vectors, testing the hypothesis that transmission has already been interrupted in North Hulu Sungai District. The study was conducted in Pihaung Village which is an endemic filariasis village, which adult filarial mosquito vectors were collected by using double net-trapped human bait method with modification. Abundance, species dominance were analyzed and PCR-based to determine DNA filarial of suspected vector. Total of 942 mosquitoes from five genera Anopheles, Aedes, Armigeres, Culex and Mansonia were captured at both sites. Of which, Mansonia has the highest relative abundance $29.96 \%$. In this study periode resulted Mansonia dives Man Hour Density and Man Biting Rate were 4.7 and 10.5 respectively. PCR examination were detected Brugia malayi DNA on Mansonia as suspected vector in Pihaung Village. This study conclude the existing of Brugia malayi DNA in this area highlighting potential risk for the re-emergence of LF transmission. This study recommends routine vector control and strengthen surveillance is required to continuously monitor the filarial suspected vector density.
\end{abstract}

Keywords: filariasis, Mansonia, microfilaria, Pihaung village

\section{INTRODUCTION}

Filariasis is one of those diseases requiring a mosquito vector in the transmission process. Malayan filariasis, or filariasis malayi, is a filariasis caused by Brugia malayi infection. B. Malayi can be divided into two variants that are living in humans, and who live in humans and animals. B. Malayi usually infected animals include apes and cats. B. Malayi is zoonotic because in addition to transmitted through mosquitoes from humans to humans also can be from animals (cats and primates) to humans [1].

In the Southeast Asian region, including Indonesia, the mosquito genus Mansonia serves as a vector filariasis of the species B. malayi1. Some Mansonia species can be a subperiodic type B. malayi vector of Nokturna. At Muaro Jambi Regency There are six types of Mansonia mosquitoes that are mosquitoes of vector filariasis namely Ma. Uniformis, Ma. Annulifera, Ma. Dives, Ma. Bonneae, Ma. Annulata, and Ma. Indiana [2, 3].

The principle of controlling filariasis in Indonesia includes two aspects of deciding on the chain of transmission and treatment of defects in patients with filariasis. The disconnection of transmission of filariasis is done by means of administration of mass prevention drugs (POPM) and vector control. In addition to handling sufferers with treatment and care to prevent and limit defects also guided vector control. It is indispensable in vector control planning, and will give maximum results when there is conformity between vector behaviour as target and control method applied [3].

The research site is the village of Pihaung district of Haur Gading Regency north of South Kalimantan province which is endemic B. malayi zoonotic. The selection of district location based on the results of the BAG-1 in the North Hulu Sungai District held Subdit P2 Filariasis in 2016. Pihaung Village is one of five endemic filariasis villages in the North Hulu Sungai District. The village is surrounded by swamp and rubber forest. Most of the livelihoods of local people are rubber farmers. Mosquitoes as vectors of filariasis are instrumental in the dispersing of filariasis related to environmental conditions and the behavior of local communities. People in Pihaung village usually go to the garden at night. This is potentially a direct contact with a vector mosquito, considering its development habitat around the plantation. This article aims to determine the diversity of mansonia mosquitoes and Yantze role in the transmission of filariasis in Pihaung village in the district of 
North Hulu Sungai South Kalimantan Province. The benefits of this article are expected to be known to the types of mosquito vectors, dissemination, and transmission of filariasis in Pihaung village of North Hulu Sungai Regency, South Kalimantan Province.

\section{METHOD}

This research is a survey research (spot survey) and data collection cross sectional. Research location is done in Pihaung village, Haur Gading District, North Hulu Sungai District of South Kalimantan Province in May to July 2017. A vector survey (mosquito) is performed to see the mosquito species containing the larvae L1, L2 and L3. The implementation is 2 times, with a time lapse of 1 month, at 3 points/location in the village Pihaung Hulu Sungai Utara District for 2 consecutive nights. The methods used are modification of human landing collection in mosquito nets. The research samples were all mosquitoes that were caught at the time of research. The sampling is purposif based on the characteristics and properties of previously known populations. Data collected in the form of all adult mosquitoes include density, frequency captured, blood sucking activity, and the presence of Microfilaria in Reservoar. Analysis of the data is done descriptively. The methods used are modification of human landing collection in mosquito nets. In this study used three houses as a place of mosquito collection. This mosquito capture is done on every home with two collectors (catcher) each placed inside and outside the house. Mosquito capture is carried out from 17:00 until 06:00. The arrest is made every hour for 45 minutes and breaks 15 minutes. The mosquito is then inserted into the paper cup covered with gauze. The mosquito that has been captured is then turned off by using chloroform and identified using the identification keys of Depkes 20081, and WRBU (Walter Reed Biosystematics Unit) 1 (2014). The Data was analyzed to determine the abundance of nisbi, frequency, dominancy figures, and mosquito density expressed in the value of MHD (Man Hour Density) 4. The analysis uses the following calculations:

$$
\begin{array}{ll}
\text { Abundance }=\frac{\text { ratio of individual species of mosquitoes acquired }}{\text { total number of mosquito species acquired }} \times 100 \% & {[\mathrm{II}]} \\
\text { Frequency }=\frac{\text { number of arrests species of mosquitoes }}{\text { total number of arrests }} & \text { [II] } \\
\text { A species dominancy }=\text { Abundance } x 100 \% & \text { [III] } \\
M H D=\frac{\text { Total number of mosquitoes collected }}{\text { number of colector } x \frac{45}{60 x} \times \text { Total time spent for collection in hours }} & \text { [IV] }
\end{array}
$$

The abundance of relative is the ratio of individual species of mosquitoes to the total number of mosquito species acquired and expressed in percent (Formula I). The frequency of the caught mosquito is calculated based on comparisons between the number of arrests of certain species of mosquitoes against the total number of arrests (Formula II). A species dominancy is calculated based on the multiplication between the abundance of the relative and the frequency of mosquitoes caught in the species at one time of arrest (Formula III). Man Hour Density (MHD) Declares the density of mosquitoes that contact with man in an hour (/orang/hour) (Formula IV) [1].

This research uses people's bait to require research ethics. This research has been declared to pass the test and obtain a research letter from the Ethics committee of the body of conduct of Litbangkes RI number LB. 02.01.2/KE/67/. All subjects involved in the study as a body bait person have been asked informed consent and are willing to engage in this research.

\section{RESULTS AND DISCUSSION}

Based on the results of the arrest obtained 5 mosquito genera Mansonia, Culex, Anopheles, Aedes. Coqullettidia. was captured by 942 mosquitoes. Mosquito capture shows that Mansonia dives are the most widely caught on every arrest (table 1). The highest mosquito capture occurred on the first trip and the trend decreased in number on the next trip. This is due to the availability of water in the habitat in the village of Pihaung during the rainy season. The number of mosquitoes Mansonia dives obtained as much as 254 individual adult mosquitoes while Ma. The uniformists get as many as 167 adult mosquitoes. Found the presence of Microfilarian DNA B. Malayi test result in PCR on Ma mosquito samples. Dives potentially as a vector filariasis B. malayi in the North Hulu Sungai District. The PCR method of examination is more sensitive in detecting microfilaria than surgery. Frekuensi, dominasi dan Man Hour Density (MHD).

Frequency of the capture of Ma mosquitoes. Dives and Ma. Uniformis is 1 time. It means Ma mosquitoes. Dives and Ma. Uniformers are more often caught both inside and outside the house. Mansonia mosquito type in Pihaung village is dominated by Ma. Dives in the house are $26.96 \%$ and Ma. Outside of the house is $17.73 \%$. Man Hour Density (MHD) suggests that Ma. Dives caught 4,704 per person per hour. It means the density of Ma mosquitoes. Dives are caught by more hourly people bait in compare Ma. Uniformis amounted to 3,093 per person per hour. 
Table 1. The number of mosquitoes that are caught, Relatif abudance, Species frequency, Species Dominance and mosquito density in Pihaung Village

\begin{tabular}{|c|c|c|c|c|c|c|c|}
\hline No & Mosquito Species & Total & $\begin{array}{c}\text { relative } \\
\text { abundance }\end{array}$ & $\begin{array}{c}\text { species } \\
\text { frequency }\end{array}$ & $\begin{array}{c}\text { Species } \\
\text { Dominance }\end{array}$ & $M H D *$ & $M B R^{* *}$ \\
\hline 1 & Aedes aegypti & 3 & 0.32 & 0.5 & 0.16 & 0.056 & 0.13 \\
\hline 2 & Aedes albopictus & 8 & 0.85 & 0.75 & 0.64 & 0.148 & 0.33 \\
\hline 3 & $\begin{array}{l}\text { Anopheles } \\
\text { nigerrimus }\end{array}$ & 34 & 3.61 & 1 & 3.61 & 0.630 & 1.42 \\
\hline 4 & $\begin{array}{l}\text { coquillettidia } \\
\text { crassipes }\end{array}$ & 17 & 1.80 & 1 & 1.80 & 0.315 & 0.71 \\
\hline 5 & $\begin{array}{l}\text { coquillettidia } \\
\text { nigropunctatus }\end{array}$ & 1 & 0.11 & 0.25 & 0.03 & 0.019 & 0.04 \\
\hline 6 & Culex annulus & 10 & 1.06 & 1 & 1.06 & 0.185 & 0.42 \\
\hline 7 & Culex fuscocephalus & 39 & 4.14 & 1 & 4.14 & 0.722 & 1.63 \\
\hline 8 & $\begin{array}{l}\text { Culex } \\
\text { quinquefasciastus }\end{array}$ & 224 & 23.78 & 1 & 23.78 & 4.148 & 9.33 \\
\hline 9 & Culex sitiens & 1 & 0.11 & 0.25 & 0.03 & 0.019 & 0.04 \\
\hline 10 & $\begin{array}{l}\text { Culex } \\
\text { tritaeniorhynchus }\end{array}$ & 36 & 3.82 & 1 & 3.82 & 0.667 & 1.50 \\
\hline 11 & Culex vishnui & 146 & 15.50 & 1 & 15.50 & 2.704 & 6.08 \\
\hline 12 & Culex gelidus & 2 & 0.21 & 0.25 & 0.05 & 0.037 & 0.08 \\
\hline 13 & Mansonia dives & 254 & 26.96 & 1 & 26.96 & 4.704 & 10.58 \\
\hline 14 & Mansonia uniformis & 167 & 17.73 & 1 & 17.73 & 3.093 & 6.96 \\
\hline
\end{tabular}

*Man Hour Density, **Man Bitting Rate.

The number of mosquitoes caught was 942 mosquitoes with the most 3 species, namely Mansonia dives, Culex quinquefasciatus and Mansonia uniformis. The value of relative abundance and dominance species is 26.96 for Mansonia uniformis, 23.78 for Culex quinquefasciatus and 17.73 for Mansonia uniformis. Whereas the density of man hour for mosquitoes (MHD) of Mansonia dives, Culex quinquefasciatus and Mansinia uniformis are respectively 4.7, 4.1 and 2.7 and density per night are 10.58, 9.33 and 6.08 .

Based on the Minister of Health Regulation No. 50 of 2017, MHD standards for genus Culex is <1 and genus Mansonia is <5 [5], while in the capture of mosquitoes in Pihaung Village, Culex quiquefasciatus density exceeds the established quality standards, that means the density of mosquitoes has the potential to transmit filariasis in Pihaung village.

Vector identification is a primary step in the surveillance system and control of vector borne diseases [6]. In Southeast Asia including Indonesia, the genus Mansonia mosquito plays a role as a vector of filariasis from the Brugia malayi species [7]. Some Mansonian species can be Brugia malayi vectors of nocturnal subperiodic types. In Muaro Jambi District there are six types Mansonia mosquitoes which are filariasis vector mosquitoes are Mansonia uniformis, Mansonia annulifera, Mansonia dives, Mansonia bonneae, Mansonia annulata, and Mansonia Indiana [8].

Mansonia has blood sucking activity on a day and fluctuates at certain hours. Based on the time of blood sucking, several species of Mansonia mosquitoes have an activity from the beginning of the sunset until the sun rises. The peak of blood sucking activity is different for each Mansonia mosquito species due to the influence of temperature.

\section{DISCUSSION}

Based on the research results in Pihaung village It appears that the number of Mansonia mosquitoes caught heavily fluctuated throughout the night both inside and outside the house. If the data is associated with some of the invention of mosquitoes at the research site in other areas then there are 
similar Mansonia species. This may be due to environmental conditions and habitats that are not much different. Atmosoedjono (1993)[13] finds Ma. Dives, Ma. Uniformis, Ma. Annulifera, Ma. Annulata, and Ma. Bonneae in Tanah Intan Province of South Kalimantan using Bare Leg Collection and Light Trap methods. Santoso (2015) 14 found Ma. Indiana positively contains DNA worm Filaria in East Tanjung Jabung Regency. The potential vector of B. Malayi in Sumatra, Kalimantan and Sulawesi is the Ma mosquito. Uniformis, Ma. Annulata, Ma. Dives, Ma. Indiana, An. Peditaeniatus, and An. Nigerimus.

B. malayi subperiodic Vector in Kalimantan region is Mansonia spp. and the most widely found is Ma. Uniformis. Many of these mosquitoes live in a swamp surrounded by forests. In Sulawesi vector B. malayi are Anopheles and Mansonia spp mosquitoes. Four mosquitoes as the main vector is An. Barbirostris, Ma. Uniformis, Ma. Dives and Ma. indiana1. Mansonia mosquitoes have a blood sucking activity at night and fluctuate at certain hours. Based on the time of sucking blood some of the mosquito species Mansonia has activity at the beginning of sunset until sunrise. The peak activity sucks different blood every Mansonia mosquito species because of the influence of temperature, and the humidity that can cause increase or decrease the presence of Mansonia mosquitoes somewhere. Mansonia spp. in Pihaung village is a permanent puddle of swamp water, which is always water throughout the year. This caused mosquitoes to use the place as habitat. Mansonia's mosquito habitat is a key factor in the high mosquito population of Pihaung village. The pre-stage mosquito is growing in the swamp. Mansonia Mosquito Larva takes oxygen through the roots of aquatic plants. The larvae of this larva are thrust in the roots of the plant. Mansonia mosquitoes love the plants Pistia stratiotes and Echhornia crassipes compared to Azolla piñata [15].

This is in accordance with the existence of such crops along the swamp where research is conducted. Pihaung Village is a village located on the edge of the swamp. In addition, along the swamp flow is a rubber forest production as a land or livelihood of local residents. The activity of the people in the rubber plantation is from midnight until early morning. It was at this time that the inhabitants of Pihaung village went to the rubber plantation and potentially a large occurrence of the Filarian transmission from mosquitoes to humans. If this is associated with Mansonia mosquito bite activity, show that these mosquitoes are active all night. Even the arrest that was done in the morning was a lot of finding Mansonia mosquitoes. It means Mansonia's mosquito population is very high in the village.

The results of the collection in Pihaung village showed that Ma mosquitoes. Dives are the most dominant type compared to other mosquito species on the arrest of body bait in the house. Ma mosquitoes. Uniformis is a genus of mosquitoes that dominate when the collection is done in KENYA [15]. Ma mosquitoes. Annulata, Ma. Uniformis, Ma. Indiana and Ma. Bonneae is haunted by the swamp. Ma. The uniformists have a high population in April - October and have a MHD 11.5 bite per person per hour. Ma. Annulata has MHD 31.7 bites per person per hour. Ma. Dives have a MHD of 3.0 bites per person per hour. In general, Mansonia's mosquito population increases in April - October and peaks in July.
While Ma. Uniformis and Ma. Indiana has a high density in April - August. Ma mosquitoes. Annulata and Ma. Bonneae usually have high density in August - Desember4. Ma. Africana and Ma. The Uniformers starred as the Wuchereria bancrofti vector in Ghana ${ }^{16}$. While in Tanzania Culex Quinquefasciatus is the main vector W. bancrofti [17].

The spread of filariasis is very closely related to poor sanitation in the township. Most of the propagation of filariasis is in rural compared to perkotaan [18]. The spread of filariasis is also influenced by environmental conditions i.e. temperature, vegetation, and land slope that will support the diversity of vector [7], so it should be done with treatment, vector control and preventing contact with vectors. Vector control and mass treatment systems must be supported by Microfilaria control in Reservoar. This is done to break the chain of transmission. Vector control in Ghana uses pesticides as an effort to support the mass-treatment program. Anopheles mosquitoes become the main vector before Mansonia spp. proved to be the B. Malayi vector at Ghana [19]. Measurement of the factors of filariasis infection is necessary to determine the policy in disconnecting the transmission such as vector ecology and parasites so as to predict the incidence of disease in a daerah [20]. The survey to determine the presence of microfilaria is necessary after the elimination program filariasis [20]. The importance of the knowledge of the ecology of Vector filariasis, the vector relationship with parasites and the theory of mosquito vectors with the parasitic is indispensable in vector control in filariasis elimination program. In addition, migration of residents from villages to other Filariasis [21] villages.

The filariasis control Program should be adjusted to the local conditions of both the social and geographic communities while referring to the government program. Climate change will affect the spread of the ditularkannya [22] vector and disease.

Given the habitat of Mansonia spp. In this area is a permanent water puddle hence the control of the stadium (larva) is an appropriate way of lowering the vector population density. The control method can be the clearance of mosquito breeding habitat from aquatic plants which is where Mansonia mosquito larva is gaining oxygen. Control activities in the form of habitat cleansing from the puddle of water and plants that live in the water can indirectly reduce the diversity of mosquitoes and break chains of disease transmission [23].

Another control that can be done is the use of mosquito nets as one way people to protect themselves against mosquito bite vector. This is the right way given the peak blood sucking mosquito vector occurs at night until early morning. Control by using a mosquito net with insecticide for control of malaria Vector was also able to reduce the number of filariasis [21]. People are also encouraged to reduce activities outside the home at night and use Repelen or mosquito repellent. Besides vector control, reservoir control is also necessary to be a source of transmission of filariasis [14]. 
[7] Cano J, Rebollo MP, Golding N, Pullan RL, Crellen T, Soler A, et al. The global distribution and transmission limits of lymphatic filariasis: Past and present. Parasites and Vectors. 2014;7(1):1-19.

[8] Santoso S, Yahya Y, Salim M. Penentuan jenis nyamuk Mansonia sebagai tersangka vektor filariasis Brugia malayi dan hewan zoonosis di Kabupaten Muaro Jambi. Media Litbangkes. 2014;24 No 4:181-90.

[9] Ridha MR. Bionomik Mansonia uniformis dan Mansonia dives sebagai Vektor Filariasis pada Beberapa Wilayah di Kalimantan. BALABA. 2018;14(1):63-70.

[10] Turell MJ. Members of the Culex pipiens Complex as Vectors of Viruses 1 . J Am Mosq Control Assoc. 2012;28(4s):123-6.

[11] Guo XX, Li CX, Deng YQ, Xing D, Liu QM, Wu Q, et al. Culex pipiens quinquefasciatus: A potential vector to transmit Zika virus. Emerg Microbes Infect. 2016;5(9):e1025.

[12] Samy AM, Elaagip AH, Kenawy MA, Ayres CFJ PA. Climate Change Influences on the Global Potential Distribution of the Mosquito Culex quinquefasciatus, Vector of West Nile Virus and Lymphatic Filariasis. PLoS One. 2016;11(10):e0163863.

[13] 1Rates I, Natural OF, In OFF. of Filariasis in Tanai-I Intan ,. 1993;21(2).

[14] District T. Deteksi mikrofilaria Brugia malayi pada nyamuk Mansonia spp dengan pembedahan dan metode PCR di Kabupaten Tanjung Jabung Timur. 2015;7(April):29-35.

[15] Ghosh A, Biswas D, Chatterjee SN, Bengal W. Host Plant Preference of Mansonia Mosquitoes. 2006;142-4.

[16] Ughasi J, Bekard HE, Coulibaly M, Adabie-gomez D, Gyapong J, Appawu M, et al. Mansonia africana and Mansonia uniformis are Vectors in the transmission of Wuchereria bancrofti lymphatic filariasis in Ghana. 2012;15 .

[17] Irish SR, Moore SJ, Derua YA, Bruce J, Cameron MM. Evaluation of gravid traps for the collection of Culex quinquefasciatus, a vector of lymphatic filariasis in Tanzania Evaluation of gravid traps for the collection of Culex quinquefasciatus, a vector of lymphatic filariasis in Tanzania. 2012;(October).

[18] Simonsen PE, Mwakitalu ME. Urban lymphatic filariasis. 2013;35-44.

[19] LA, Wilson MD, Bockarie MJ, Boakye DA. Diversity and transmission competence in lymphatic filariasis vectors in West Africa, and the implications for accelerated elimination of Anopheles -transmitted filariasis. 2012;1-6.

[20] Slater H, Michael E. Predicting the Current and Future Potential Distributions of Lymphatic Filariasis in Africa Using Maximum Entropy Ecological Niche Modelling. $2012 ; 7(2)$.
6] Braks M, Medlock JM, Hubalek Z, Hjertqvist M, Perrin $\mathrm{Y}$, Lancelot R, et al. Vector-borne disease intelligence: Strategies to deal with disease burden and threats. Front Public Heal. 2014;2(DEC). 
[21] Ramaiah KD. Population Migration : Implications for Lymphatic Filariasis Elimination Programmes. 2013;7(3):14.

[22] Anorital dan Rita Marleta Dewi. Pengetahuan, sikap dan Perilaku Penderta filariasis malayi selama pelaksanaan pengobatan di kabupaten Tabalong Kalimantan Selatan. Media litbangkes vol XIV no 4 , 2014 , 42-50. 2004;42-50.

[23] Ambarita LP. LAPORAN AKHIR PENELITIAN Studi Evaluasi Eliminasi Filariasis di Indonesia Tahun 2017 (Studi Multisenter Filariasis). 2017;2017. 